\title{
Training On the Use of Google Form for Learning Assessment in Elementary School During the Covid-19 Pandemic
}

\author{
Sendi Fauzi Giwangsaa), Nana Jumhana, Arie Rakhmat Riyadi, Ruswandi \\ Hermawan, Evi Rahmawati, Ari Arasy Magistra, Rahmania Mutiasari, Annisa Nurul \\ Fadhila
}

\author{
Program Studi PGSD Universitas Pendidikan Indonesai, Indonesia \\ a)Corresponding Author: sendifauzigiwangsa@upi.edu
}

\begin{abstract}
The existence of the COVID-19 pandemic has made the learning process that was originally face-to-face to online distance learning. One aspect that is still not optimal is in the assessment of learning. There are many applications that can be used by teachers in the implementation of online learning assessments. One of the online assessments that is often used is google form. This google form platform has been widely used for online assessments such as for blinding evaluation exercises, evaluating lecturers' performance and for alternative learning evaluations. The method implemented in this training is training through the zoom meeting application and also assignments. This training is aimed at elementary school teachers. The number of participants for this training is 10 elementary school teachers from Sumedang, Bandung, Cimahi, and West Bandung areas. This training consists of three stages, namely training preparation, training implementation, and post-training control. In general, the results of the training are in accordance with the tutorials given during the training, starting from the identity page, entering questions, entering answer keys and scoring. Based on the results of the questionnaire given after the training, $95 \%$ of the respondents received a positive response. The participants responded that the training carried out was very useful and relevant to the needs of the online learning period.
\end{abstract}

Keywords: Training, Google form, Learning Assessment

\section{INTRODUCTION}

The COVID-19 pandemic has made the learning process that was originally face-to-face to distance learning. In order to keep distance learning running, it is inevitable to use technology as a suggestion in carrying out learning so it is often called online learning or online learning (Latip \& Sutantri, 2021; Marcica \& Nurmatin, 2020).

One aspect that is still not optimal is in the assessment of learning. There are many applications that can be used by teachers in implementing learning assessments during this pandemic, google form, kahoot, quizeez etc. However, the ability of teachers who are still less competent in using these various applications so that the learning carried out is less than optimal. One application that can be used for learning assessment during this pandemic is the google form application (Latip \& Sutantri, 2021; Marcica \& Nurmatin, 2020).

Learning during the COVID-19 pandemic like this, teachers must be able to choose an assessment platform. One of the online assessments that have often been used is the google form (Latip \& Sutantri, 2021; Marcica \& Nurmatin, 2020). Before using the google form for assessing learning in elementary schools, teachers must consider various things, especially supporting facilities to carry out online assessments such as facilities owned by students both in terms of tools such as laptops, computers, or cellphones as well as internet connections in students' areas to support in the ease of accessing or using this google form assessment platform.

This google form platform has been widely used for online assessments such as for blinding evaluation exercises (Mardian and Purwanto, 2017), lecturer performance assessments (Batubara, 2016) and for alternative learning evaluations (Wulandari, et al, 2019). In addition to online assessment, the google form is also widely used for learning media (lqbal et al., 2018) and also as a registration medium for the TOEFL test (Handayani et al., 2018). The use of google 
forms for various things is due to the advantages of google forms (Handayani et al., 2018; lqbal et al., 2018; Latip \& Sutantri, 2021; Marcica \& Nurmatin, 2020) including:

1. Free application, all facilities can be accessed for free provided you have a google account or email.

2. Easy to make and use, can be used either on mobile phones, laptops, or computers connected to the internet.

3. A lightweight program when run either by mobile, laptop or computer,

4. The results of responses and answers from the assessment will be collected, compiled, analyzed, and stored automatically and securely.

5. Many choices of questions, such as multiple-choice, short entry, description, checklist, liner scale, etc.

6. Easy to share either via e-mail or social media and by clicking on the link can be done directly either via mobile, laptop or computer.

\section{METHOD}

The method implemented is training through the zoom meeting application and also assignments. This training is aimed at elementary school teachers. The number of participants for this training is 10 elementary school teachers from Sumedang, Bandung, Cimahi, and West Bandung areas. This training was carried out in the context of community service (PkM) PGSD FIP UPI lecturers and several students. This training consists of three stages, namely training preparation, training implementation, and post-training control. The following is an explanation of each stage.

\section{Training Preparation}

At the training preparation stage, each PkM member is carried out to plan the training time and things that must be prepared such as selecting resource persons, preparing materials for training, making invitations for training participants, preparing training response questionnaires and compiling training rounddowns. During this preparatory stage, several online discussions were held in order to prepare the training to run optimally.

\section{Training Implementation}

The training on the use of the google form for assessment in elementary schools was held for 2 days, the 1st day containing material on how to use the google form starting from how to access, then making questions on the google form, setting the answer key and scoring, how to share the google link form to how to download and analyze the results of the assessment. While the second day is an independent assignment to make an assessment through the google form. The training on the 1st day was the provision of material regarding the use of the google form for assessment which was carried out by means of presentations and online simulations through zoom meetings to make assessments on the google form, question and answer activities regarding difficulties or things that were not understood by the participants and also occasionally interspersed with icebreaking activities to increase the spirit of the training participants.

\section{Controlling}

Controlling was carried out on the 2nd day of the training, namely by assigning participants to practice making online assessments via Google Forms. This is to ensure that participants can understand the material on the first day regarding the creation of a google form for assessment. Participants can ask the committee if they have difficulty in making an assessment through the google form facilitated through the whatsapp group. After the participant has finished making the assessment through the google form, the participant is asked to send the link to the whatsapp group for later inspection and checking of the appearance of the google form, as well as the settings in the questions made on the google form. Finally, in this training activity, participants were asked to fill out a questionnaire regarding the responses from the implementation of the training on the use of google forms for assessment in elementary schools.

\section{RESULTS}


The results of the training activity on the use of Google Forms for assessment of learning in elementary schools during the COVID-19 pandemic were carried out according to plan. The training was carried out for two days, where the first day was material on assessment and training on making google forms which was carried out online through a zoom meeting and on the second day an assignment to make questions for assessors and enter them into the google form link.

At the beginning of the training, participants were given an explanation about the use of google forms in learning. In general, teachers are familiar with Google Forms as a platform that is often used to collect data in the form of filling out forms, surveys, questionnaires, etc. However, they are not used to using Google Forms for learning assessment tools.

Furthermore, training on the use of the google form for assessment of learning begins by providing tutorials for accessing the google form, setting up the google form for assessment (quiz), making the initial page for identity, and inputting questions along with their keys and scoring on the google form. In this training, the focus is on four multiple choice questions because there are facilities for adding keys and scoring so that it will be very easy for teachers to assess learning in elementary schools. Then the teachers were also trained to include pictures in the questions and in the answer choices. After the training on inputting questions and choosing answers, the teachers were given an explanation of the features in the google form such as randomizing the order of questions or answer choices to minimize student cheating, doubling questions, etc.

After the explanation for making questions, the teachers then explained the tutorial for sending the google form link either via e-mail or via social media such as Whatsapp. Then the teachers were given a tutorial on how to get the results of the assessment in the form of an excel file that already contained the correct or incorrect value or number of scores.

After the explanation regarding the making of the google form for the learning assessment was carried out, a question and answer session was held about things that were not understood by the teachers. In general, teachers can follow any explanation given without many problems, while some questions arise, including those relating to the process of setting up the google form for quizzes, entering equations for math problems, setting answer keys and scoring and modifying links from the google form.

On the second day, where the participants were asked to practice making an assessment in the form of a google form link, the google form link was then submitted to the committee. At this controlling stage, in general, it is in accordance with the tutorial given earlier starting from the identity page, entering questions, entering answer keys and scoring. However, some minor errors were also found, such as typing the question incorrectly, the choice of which had an empty or more option and not separating the part between identity and the question so that the identity and the question were in one part.

In addition, a check was also carried out by doing a simulation of filling out the google form assessment link by several teachers by filling in the google form link that had been made by other participants. This is done with the aim of ensuring that all question sets can be used from start to finish. After the training, the participants were given a questionnaire to see the responses of the divers participating in the training. Based on the results of the questionnaire, $95 \%$ of participants considered that the training activities were very useful and relevant to the needs of teachers during online learning as it is today.

\section{DISCUSSION}

The existence of the COVID-19 pandemic also has an impact on education, especially the learning process which cannot be carried out face-to-face with the aim of reducing the risk of spreading the corona virus. So, inevitably, teachers are looking for alternative ways to streamline the learning process, one of which is online learning through video conferences such as google meet, zoom meeting, etc., or through google classroom or discussions or assignments via whatsapp (Handayani et al., 2018; lqbal et al. al., 2018). 
Online learning certainly has an impact on the assessment of learning which is also carried out online. In online assessment, there are many platforms that can be used by teachers, such as Google Classroom, Quizizz, Kahoot, etc. One of the platforms that can be used for online assessment is Google Forms. This google form platform has been widely used for online assessments such as for blinding evaluation exercises (Mardian and Purwanto, 2017), lecturer performance assessments (Batubara, 2016) and for alternative learning evaluations (Wulandari, et al, 2019). In addition to online assessment, the google form is also widely used for learning media (lqbal et al., 2018) and also as a registration medium for the TOEFL test (Handayani et al., 2018). The use of google forms for various things is due to the advantages of google forms (Handayani et al., 2018; lqbal et al., 2018; Latip \& Sutantri, 2021; Marcica \& Nurmatin, 2020) including:

1. Free application, all facilities can be accessed for free provided you have a google account or email.

2. Easy to make and use, can be used either on mobile phones, laptops or computers connected to the internet.

3. A lightweight program when run either by mobile, laptop or computer,

4. The results of responses and answers from the assessment will be collected, compiled, analyzed and stored automatically and securely.

5. Many choices of questions, such as multiple choice, short entry, description, checklist, liner scale etc.

6. It is easy to share either via e-mail or social media and by clicking on the link it can be done directly either via mobile, laptop or computer.

This training on the use of the google form is one of the efforts made by lecturers of the PGSD FIP UPI study program to assist teachers in optimizing the online learning process, especially in the online assessment aspect through the google form. After the training on the use of the google form for assessment is carried out, it is hoped that the learning assessment process can be carried out effectively and efficiently even in limited circumstances due to the covid 19 pandemic. And the results of this training show that teachers are able to make online assessments through the google form platform. The results of the respondents from the participants also received a positive response, $95 \%$ of the respondents considered that the training carried out was very useful and relevant to the needs of teachers during the online learning period.

\section{CONCLUSIONS AND RECOMMENDATIONS}

The results of the training activity on the use of Google Forms for assessment of learning in elementary schools during the COVID-19 pandemic were carried out according to plan. The training was carried out for two days, where the first day was material on assessment and training on making google forms which was carried out online through a zoom meeting and on the second day an assignment to make questions for assessors and enter them into the google form link. On the second day, namely the controlling activity, where the participants were asked to practice making an assessment in the form of a google form link, the google form link was then submitted to the committee. At this controlling stage, in general, it is in accordance with the tutorial given earlier starting from the identity page, entering questions, entering answer keys and scoring. Based on the results of the questionnaire given after the training, $95 \%$ of the respondents received a positive response. The participants responded that the training carried out was very useful and relevant to the needs of the online learning period.

\section{ACKNOWLEDGMENTS}


We express our gratitude to Allah Subhanahu Wa Ta'ala, because for the facilities provided so that this Community Service can run smoothly. We would like to thank the UPI Research and Community Service Institute (LPPM), the Faculty of Education and the PGSD FIP UPI Study Program for providing service funds for the 2021 fiscal year. We also thank the training participants who are willing to take part in this training and also to the executive committee who have helped carry out this service activity well and smoothly. May Allah Subhanahu Wa Ta'ala reward you with the good you deserve. Amen.

\section{REFERENCES}

Batubara, H. 2016. Penggunaan google form sebagai alat penilaian kinerja dosen di Prodi PGMI UNISKA Muhammad Arsyad Al banjari. Jurnal Pendidikan Dasar Islam. Vol 8. No.1 hal 39-50

Handayani, I., Aini, Q., Cholisoh, N., \& Agustina, I. I. 2018. Pemanfaatan Google Form Sebagai Pendaftaran TOEFL (Test Of English as a Foreign Language) Secara Online. Jurnal Teknoinfo, 12(2), 55. https://doi.org/10.33365/jti.v12i2.73

lqbal, M., Rosramadhana, R., Amal, B. K., \& Rumapea, M. E. 2018. Penggunaan Google Forms Sebagai Media Pemberian Tugas Mata Kuliah Pengantar IImu Sosial. Jupiis: Jurnal Pendidikan IImu-IImu Sosial, 10(1), 120. https://doi.org/10.24114/jupiis.v10i1.9652

Latip, A., \& Sutantri, N. 2021. Pelatihan Pemanfaatan Google Form Sebagai Platform Penilaian Akhir Tahun di SMA Edu Global Bandung. JAHE (Journal of Human and Education), 1(1), 1-5.

Marcica, E., \& Nurmatin, S. 2020. Pemanfaatan Google Form Sebagai Evaluasi Pembelajaran Jarak Jauh. AIL-ABHATS: Jurnal Pengabdian Kepada Masyarakat, 01(01), 1-5.

Wulandari, P., Mawarni, Khotimah, H. 2019. Google Form sebagai Alternatif Evluasi Pembelajaran di SMAN 2 Kota Tangerang pada Seminar Nasional Pendidikan FKIP.. Vol 2, No.1, Halaman 321-324 


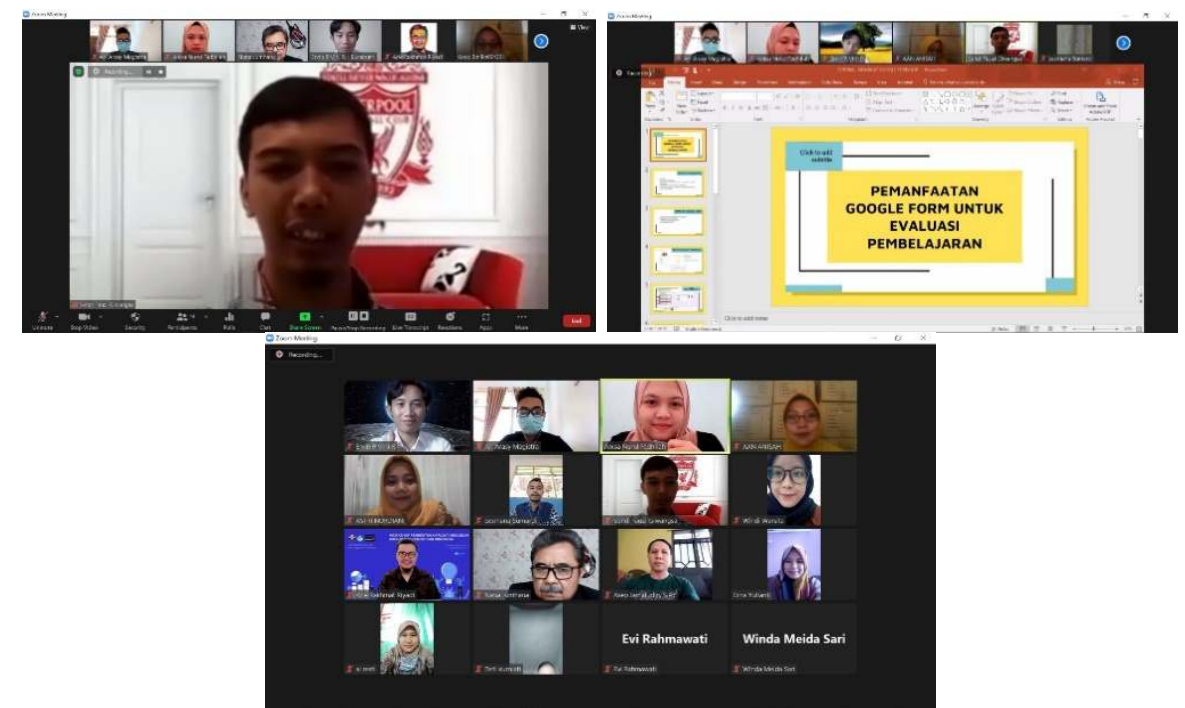

Figure 1. Training Implementation

Kegiatan pelatihan dapat meningkatkan keterampilan penggunaan google form untuk penilaian pembelajaran di SD 6 responses

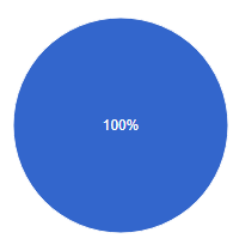

- Sangat Setuju

- Setuju

- Tidak Setuju

Materi yang disajikan dapat menambah wawasan mengenai penilaian pembelajaran di SD 6 responses

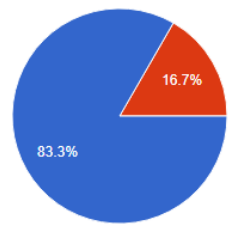

- Sangat Setuju

- Setuju

- Sidakgat Tidak Setuju

Penyajian materi cukup interaktif 6 responses

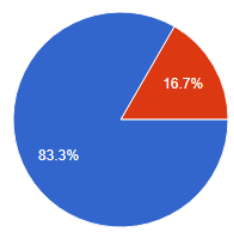

- Sangat Setuju

- Setuju

Tidak Setuju 


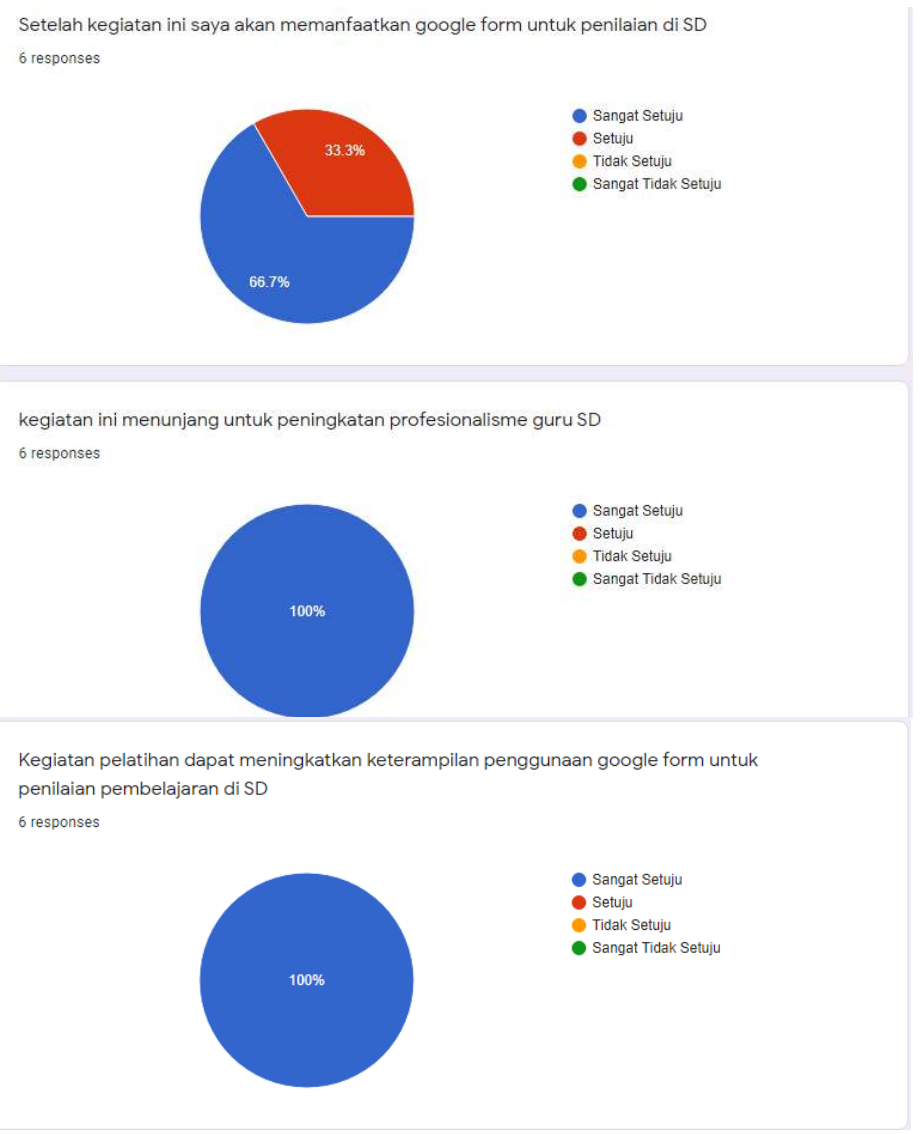

Figure 2. Training Response 